九州大学学術情報リポジトリ

Kyushu University Institutional Repository

\title{
A new potamonid crab, Potamon (Geothelphusa) miyazakii sp. nov., as an intermediate host of the lung-fluke from Formosa
}

Miyake, Sadayoshi

Zoological Laboratory, Department of Agriculture, Kyushu University

Chiu, Jui-Kuang

Department of Parasitology College of Medicine National Taiwan University

https://doi.org/10.5109/22736

出版情報 : 九州大学大学院農学研究院紀要. 13 (3)，pp.595-600，1965-05. Kyushu University バージョン：

権利関係 : 
Journal of the Faculty of Agriculture, Kyushu University, Vol. 13, No. 3 May 30, 1965

A new potamonid crab, Potamon (Geothelphusa) miyazakii

sp. nov., as an intermediate host of the lung-fluke from Formosa ${ }^{1)}$

Sadayoshi MiYAKE ${ }^{2)}$ and Jui-Kuang $\mathrm{CHIU}^{3)}$

So far as known, the following four species of Potamonidae have been reported from Formosa, i.e. Potamon (Geothelphusa) dehaani (White, 1847), Potamon (G eothel phusa) formosanus Parisi, 1916, Potamon (Potamon) rathbuni de Man, 1914 and Parathelphusa(Parathelphusa) sinensis ( $\mathrm{H}$. Milne Edwards, 1854). In the course of a brief review of the species of the genus Potamon as intermediate hosts of the lung-fluke from Formosa, we have found an undescribed species nearly allied to Potamon dehaani and Potamon (Geothelphusa) sakamotoanus Rathbun, 1904 from Okinawa-jima, the Ryukyu Islands.

This new species is named in honour of Professor Ichiro Miyazaki, Head of the Department of Parasitology, Faculty of Medicine, Kyushu University from whom we have valuable advice and by whose kind guidance the present study has been carried out. We are also indebted to Mr. H. Minei, Zoological Laboratory, Faculty of Agriculture, Kyushu University, for the preparations of photographs and measurements in the figures and tables.

$$
\text { P O T A M O N I D A E }
$$

\section{Potamon (Geothelphusa) miyazakii sp. nov.}

New Japanese name : Miyazaki-sawagani

Diagnosis.-Carapace medium-sized, distinctly larger than Potamon dehaani (White), but not larger than Potamon sakamotoanus Rathbun. Breadth of orbit relatively shorter than the two above-mentioned

1) Contributions from the Zoological Laboratory, Faculty of Agriculture, Kyushu University, no. 336 .

2) Zoological Laboratory, Faculty of Agriculture, Kyushu University, Fukuoka.

3) Department of Parasitology, College of Medicine, National Taiwan University, Taipei, Taiwan (Formosa). 
species. The H-shaped groove of the middle portion of the cervical groove is indicated by a very deep depression. The branchial groove is indicated by a very deep depression. The branchial lobule and the two urogastric lobules can be seen in a deep transverse depression being continued to the $\mathrm{H}$-shaped groove in the middle of the branchial region. Anterolateral margins form a distinct crest and are not separated to the outer orbital crest. Ambulatory legs more broader than the allied two species. Carapace and legs dark purple in living colour.

Description of types.-Carapace a little broader, the breadth being only about one and one-fourth times the length. The upper surface slightly convex fore and aft in anterior regions, and smooth but punctate in all regions. Anterior margins of epigastric and hepatic lobes are distinct by the depression of the frontal and orbital regions, but those of posterior margins indistinct by faint shallow grooves. Epigastric lobe is distinctly divided into two lobes by a median groove which extends backwards. The urogastric region is separated in two lobules laterally by a short distance. The branchial lobule is conspicuous and located to outside of the $\mathrm{H}$-shaped groove in the branchial region.

In the middle of the branchial region there is a broad, deep depression between the branchial lobule and the middle of the posterolateral region. The upper surface of the branchial region is ornamented with short striae near the posterolateral margin and a short crest near the posterolateral corner. This short crest runs outsides and continues to the posterolateral margin. These remarkable depressions can not be seen in the two allied species.

The anterolateral margin forms a distinct, continuous crest, and is not beaded in the holotype and allotype, but in one of the paratypes being smaller specimen it is ornamented with same-sized tubercles or granules.

The suborbital, subhepatic and pterigostomian regions are smooth in the holotype and allotype. In the paratypes, however, the suborbital and the subhepatic regions are granulose, and the pterygostomian region is ornamented with short hairs. The pleural groove is distinct and accompanied with a crest on the inner lower margin of the subhepatic region. The crest in the pleural groove is smooth in the holotype and allotype, but it is ornamented with short hairs in the paratypes or smaller specimens. The sternum of the third maxilliped is furnished with short hairs on the posterior margin, but in the two allied species not hairy.

Chelipeds smooth and unequal, right one being larger in the holotype and allotype, but left one larger in the paratypes. Merus with short striae on the upper distal margin. Wrist with a short depression longitudinally and on inner margin armed with a short tooth 
being accompanied with one more small tooth or tubercle downwards on inner surface. Fingers of the chela armed with small obtuse teeth being counted ten teeth on the movable finger and fifteen ones on the immovable finger in the types. There is a small gap between fingers only in larger or right cheliped in the holotype.

Ambulatory legs smooth except propodus and dactylus being spinose and hairy. Dactylus longer than propodus, and armed with spines on both upper and lower margins. Propodus with spines only on lower margin, and the distal margin being articulated the dactylus is armed with spines. Ambulatory legs are more broader than that of the two allied species. The length of the propodus is about twice as broad as the dactylus.

The sixth segment of the abdomen is longer than the last segment in both sexes, and it is distinctly longer than the two allied species (Table 2). The shape of the first pleopod is the same as that of the two allied species.

Colour in life.-Carapace and legs dark purple in colour, but the dactyli, all joints of the ambulatory legs, and both the movable and immovable fingers and all joints of the chelipeds are orange.

Types.-Holotype, male, Cl. 24.7, Cb. $31.0 \mathrm{~mm}$, Zoological Laboratory, Kyushu University (ZLKU), Cat. No. 10983; allotype, female, Cl. 26.6, Cb. $34.2 \mathrm{~mm}$, ZLKU, Cat. No. 10984; paratypes, male, Cl. 21.5, Cb. 26.8 mm, female, Cl. 26.9, Cb. 33.1 mm, ZLKU, Cat. No. 10986.

Type locality.-Alilao village of Shi-men district in Taipei County, Taiwan (Formosa). All type specimens are collected on Jan. 28, 1964 by J. K. Chiu.

Measurements and proportions of the specimens examined.-In the following tables (1-4) we have the measurements and proportions of

Table 1. Measurements and proportions of carapaces of the types and the two allied species.

\begin{tabular}{|c|c|c|c|c|c|c|}
\hline \multirow{2}{*}{$\begin{array}{c}\text { Species } \\
\text { Sex }\end{array}$} & \multicolumn{2}{|c|}{ P. miyazakii } & \multicolumn{2}{|c|}{ P. dehaani } & \multicolumn{2}{|c|}{ P. sakamotoanus } \\
\hline & $\hat{\delta}$ & 우 & $\hat{\delta}$ & q & $\hat{\delta}$ & 우 \\
\hline Carapace length (Cl) & 24.7 & 26.6 & 23.1 & 23.6 & 33.0 & 32.3 \\
\hline Carapace breadth $(\mathrm{Cb})$ & 31.0 & 34.2 & 29.6 & 29.9 & 41.8 & 40.1 \\
\hline Carapace depth $(\mathrm{Cd})$ & 14.3 & 15.1 & 13.5 & 13.2 & 19.0 & 17.7 \\
\hline Frontal breadth $(\mathrm{Fb})$ & 10.0 & 10.0 & 9.0 & 8.5 & 11.3 & 11.0 \\
\hline Front-orbital breadth (Fob) & 19.3 & 20.3 & 19.4 & 18.9 & 25.3 & 25.0 \\
\hline $\mathrm{Cl} / \mathrm{Cb}$ & .796 & .777 & .780 & .789 & .789 & .805 \\
\hline $\mathrm{Cd} / \mathrm{Cl}$ & .578 & .567 & .514 & .559 & .575 & .548 \\
\hline $\mathrm{Fb} / \mathrm{Fob}$ & .518 & .492 & .463 & .449 & .446 & .340 \\
\hline $\mathrm{Fb} / \mathrm{Cb}$ & .322 & .292 & .304 & .284 & .270 & .274 \\
\hline
\end{tabular}


Table 2. Measurements and proportions of the last two segemnts of abdomens of the types and the two allied species.

\begin{tabular}{|c|c|c|c|c|c|c|}
\hline Species & \multicolumn{2}{|c|}{ P. miyazakii } & \multicolumn{2}{|c|}{ P. dehaani } & \multicolumn{2}{|c|}{ P. sakamotoanus } \\
\hline Sex & $\hat{\rho}$ & 우 & $\hat{\delta}$ & 우 & $\hat{o}$ & 우 \\
\hline Carapace breadth & 31.0 & 34.2 & 29.6 & 29.9 & 41.8 & 40.1 \\
\hline Length of 7 th segment (L7) & 5.3 & 7.0 & 4.0 & 5.1 & 6.2 & 7.6 \\
\hline Breadth of 7 th segment (B7) & 6.2 & 12.8 & 5.8 & 12.0 & 8.3 & 16.6 \\
\hline Length of 6th segment (L6) & 4.0 & 5.4 & 3.4 & 5.2 & 5.1 & 7.7 \\
\hline Breadth of 6th segment (B6) & 8.0 & 15.7 & 7.6 & 16.0 & 10.3 & 21.9 \\
\hline $\mathrm{L} 7 / \mathrm{B} 7$ & .854 & .546 & .689 & .425 & .746 & .475 \\
\hline $\mathrm{L} 7 / \mathrm{B} 6$ & .500 & .343 & .447 & .325 & .495 & .351 \\
\hline $\mathrm{L} 7 / \mathrm{L} 6$ & 1. 325 & 1.296 & 1.176 & .980 & 1.215 & .987 \\
\hline
\end{tabular}

Table 3. Measurements and proportions of the large chelae of the types and the two allied species.

\begin{tabular}{|c|c|c|c|c|c|c|}
\hline \multirow{2}{*}{$--\frac{\text { Species }}{\text { Sex }}$} & \multicolumn{2}{|c|}{ P. miyazakii } & \multicolumn{2}{|c|}{ P. dehaani } & \multicolumn{2}{|c|}{ P. sakamotoanus } \\
\hline & $\hat{o}$ & 우 & $\hat{o}$ & 우 & $\hat{o}$ & 우 \\
\hline Carapace breadth & 31.0 & 34.2 & 29.6 & 29.9 & 41.8 & 40.1 \\
\hline Length of palm (Lp) & 10.0 & 8.5 & 10.0 & 6.7 & 15.6 & 11.0 \\
\hline Height of palm (Hp) & 14.7 & 12.5 & 14.7 & 8.8 & 21.2 & 14.5 \\
\hline Length of dactylus (Ld) & 15.6 & 15.0 & 17.6 & 11.0 & 25.7 & 16.3 \\
\hline Length of chela (Lch) & 24.0 & 23.7 & 24.2 & 18.2 & 37.3 & 26.7 \\
\hline $\mathrm{Lp} / \mathrm{Hp}$ & .680 & .680 & .680 & .761 & .735 & .758 \\
\hline $\mathrm{Lp} / \mathrm{Ld}$ & .641 & .566 & .568 & .609 & .607 & .674 \\
\hline $\mathrm{Hp} / \mathrm{Lch}$ & .612 & .527 & .607 & .483 & .568 & .543 \\
\hline $\mathrm{Ld} / \mathrm{Lch}$ & .647 & .632 & .727 & .804 & .689 & .610 \\
\hline
\end{tabular}

Table 4. Measurements and proportions of the last two segments of the right second ambulatory legs of the types and the two allied species.

\begin{tabular}{|c|c|c|c|c|c|c|}
\hline \multirow{2}{*}{$\begin{array}{c}\text { Species } \\
\text { Sex }\end{array}$} & \multirow{2}{*}{$\begin{array}{l}P . \\
\hat{0}\end{array}$} & yazakii & \multicolumn{2}{|c|}{ P. dehaani } & \multicolumn{2}{|c|}{ P. sakamotoanus } \\
\hline & & 우 & $\hat{o}$ & 우 & $\hat{o}$ & 우 \\
\hline Carapace breadth & 31.0 & 34.2 & 29.6 & 29.9 & 41.8 & 40.1 \\
\hline Length of propodus (Lp) & 7.2 & 9.2 & 7.8 & 8.0 & 13.0 & 12.8 \\
\hline Breadthof propodus $(\mathrm{Bp})$ & 4.0 & 4.2 & 3.5 & 3.3 & 4.3 & 4.3 \\
\hline Length of dactylus (Ld) & 8.8 & 11.8 & 10.0 & 10.1 & 14.7 & 14.3 \\
\hline $\mathrm{Bp} / \mathrm{Lp}$ & .555 & .456 & .448 & .412 & .330 & .335 \\
\hline $\mathrm{Lp} / \mathrm{Ld}$ & .818 & .779 & .780 & .792 & .884 & .895 \\
\hline
\end{tabular}

the carapace and legs of the holotype and allotype of P. miyazakii, and for purposes of comparison have included similar measurements 
and proportions of two typical specimens, a male and a female, of each of the two allied species, $P$. dehaani and $P$. sakamotoanus. All the measurements are in millimetres.

Ecology.--Usually the crabs inhabit the muddy ditches of hilly area and seldom found in brooks, and are infected with metacercariae of two lung-flukes, Paragonimus westermani (Kerbert, 1878) and $P$. iloktsuenensis Chen, 1940 in the Taipei County of Taiwan. This crab is called "Ang-ka-hasien" (" red leg immortal crab ") $)^{1)}$ by the inhabitants. It is not consumed as food.

Distribution.-At present known only from Taipei County and the suburb of Keelung City in Formosa as noted below: Taipei County (a. Shen-keng, b. Alilao, Shi-men, c. Nei-hu, d. Shih-lin, e. Wu-tankeng, f. Ping-lin) and the suburb of Keelung City?

\section{REFERENCES}

Alcock, A. 1910a Catalogue of the Indian decapod crustacea in the collection of the Indian Museum. Part I. Brachyura. Fasc. II. The Indian freshwater crabs. Potamonidae. Calcutta. 130 pp. 14 pls.

Alcock, A. 1910b On the classification of the Potamonidae (Telphusidae). Rec. Ind. Mus., Part IV, 5 (26): 253-261.

Balss, H. 1937 Potamoniden (Dekapoda, Brachyura) der Philippinen und des Malayischen Archipels. Internat. Rev. Hydrobiol. u. Hydrogr., 34 (3-5) : 1-43-187.

Chiu, J. K. 1962a Two species of Paragonimus occurring at Alilao village of Taipei County, Taiwan (Formosa). Kyushu J. Med. Sci., 13: 51-66.

Chiu, J. Ii. 196'2b Intermediate hosts Paragonimuswestermanii at Shen-keng district of Taipei County, Taiwan (Formosa). J. Parasit., 48 (3): 423-426.

Koba, K. 1936 Studies on the Japanese Potamonidae (1). Notes on Potamon rathbuni de Man, as a second intermediate host of Paragonimuswetermanii (Kerbert) in Formosa. Trans. Nat. Hist. Soc. Formosa, 26 (151): 164-174 (in Japanese).

de Man, J. G. 1914 Note sur quelques crustaces decapodes brachyures terretres et d'eau douce appartenant au Musée Civique de Gènes. Ann. Mus. Civ. Stor. Nat. Genova, ser. 3, 6: 122-138, pls. 2-3.

Minei,H. 1963 On the habitat and ovigerous habit of the female of a freshwater crab, Potamon (Geothelphusa) sakamotoanus Rathbun from Okinawa-jima Island, the Ryukyu Islands. Sci. Bull. Fac. Agric. Kyushu Univ., 20 (4): 36j-372 (in Japanese with English summary).

Parisi, B. 1916 Potomonidae, in : I decapodi giapponesi del Museo di Milano. IV. Cyclometopa. Atti della Soc. Ital. Nat., 55: 153-170, pls. VII-X.

Rathbun, M. J. 1898 Description of three new species of fresh-water crabs of the genus Potamon. Proc. Biol. Soc. Washington, 12: 27-30, pl. 1.

1) 台沙名，紅脚仙。

2) 分 7 i 。 台北県 (a. 深坑, b. 阿里莸, 石門郷 (基産地), c. 内湖, d. 士林, e. 武丹坑,

f. 坪林）扣よび基隆术郊外。 
Rathbun, M. J. 1904. Les crabs d'eau douce (Potamonidae). Nouv. Arch. Mus. Hist. Nat., Paris, ser. IV, 6: 225-312, 10 pls.

White, A. 1847 List of the specimens of crustacea in the collection of the British Museum, London, pp. i-viii, 1-149.

\section{Explanation of Plate 13}

1. Holotype, male of Potamon (Geothelphusa) miyazakii sp. nov., x 1.

2. Allotype, female of the same, $\times 0.9$.

3. A male of Potamon (Geothelphusa) dehaani (White) from Fukuoka Prefecture, Kyushu, $\times 1.1$.

4. A male of Potamon (Geothelphusa) sakamotoanus Rathbun from Okinawa- jima, the Ryukyu Islands, $\times 0.8$. 

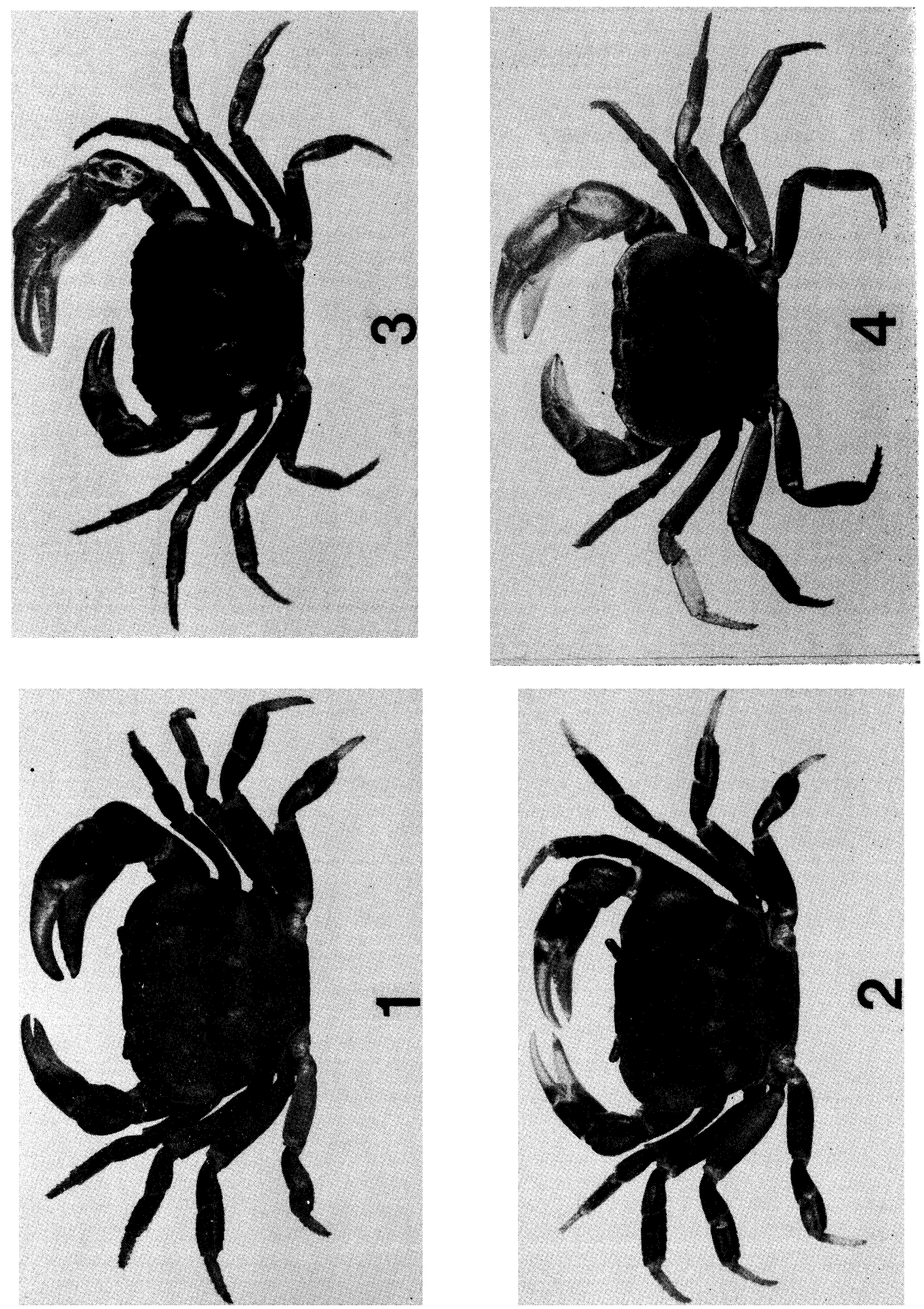

A new potamonid crab from Formosa 


\section{Explanation of Plate 14}

1. Frontal view of the holotype, male.

2. Ventral view of the same.

3. Frontal view of Potamon(Geothelphusa) dehaani (White), male from IFukuoka Prefecture, Kyushu ( 21.2 x $28.2 \mathrm{~mm})$.

4. Ventral view of the same.

5. Frontal view of Potamon(Geothelphusa) sakamotoanus Rathbun, male from Okinawa- jima, the Ryukyu Islands $(28.0$ x $35.9 \mathrm{~mm})$.

6. Ventral view of the same. 
Jour. Fac. Agric., Kyushu Univ., Vol. 13

Plate 14

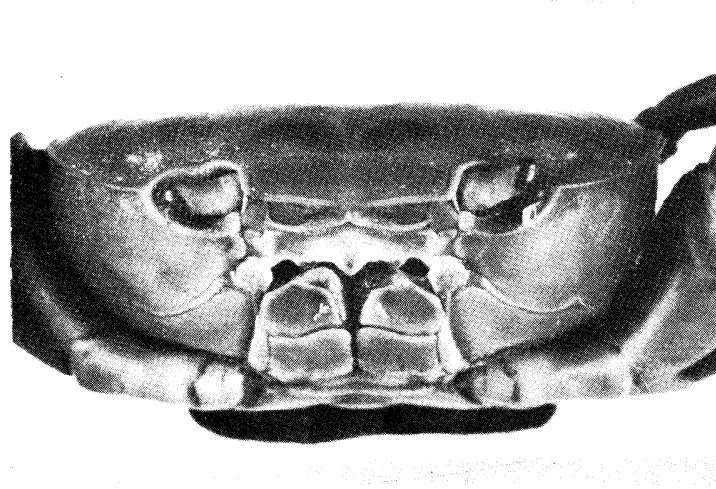

1

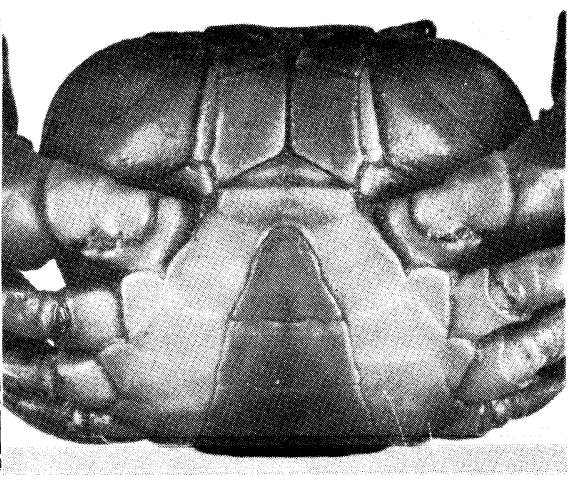

2

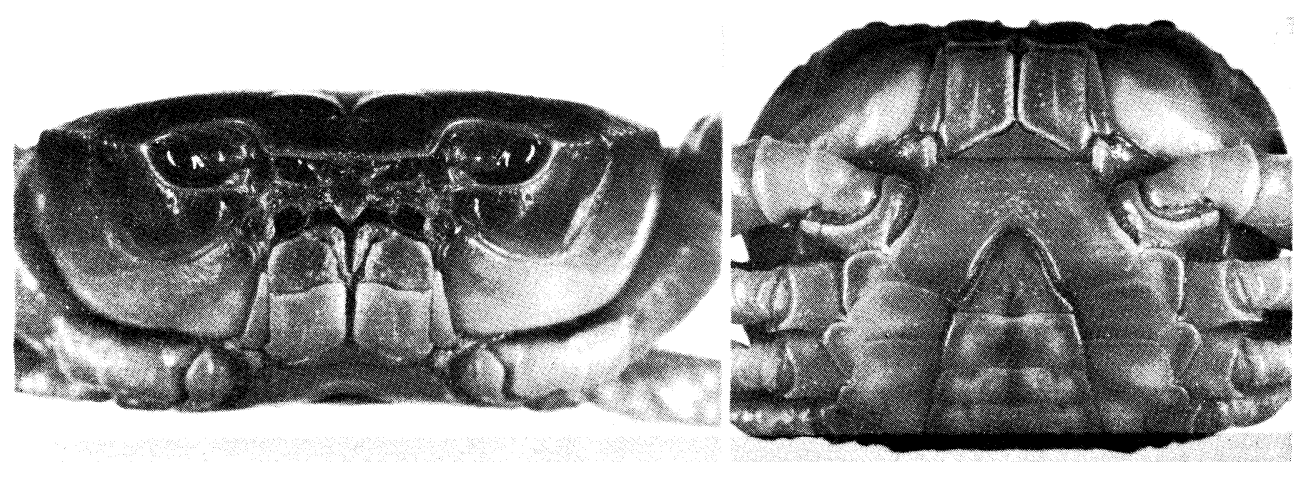

3

4
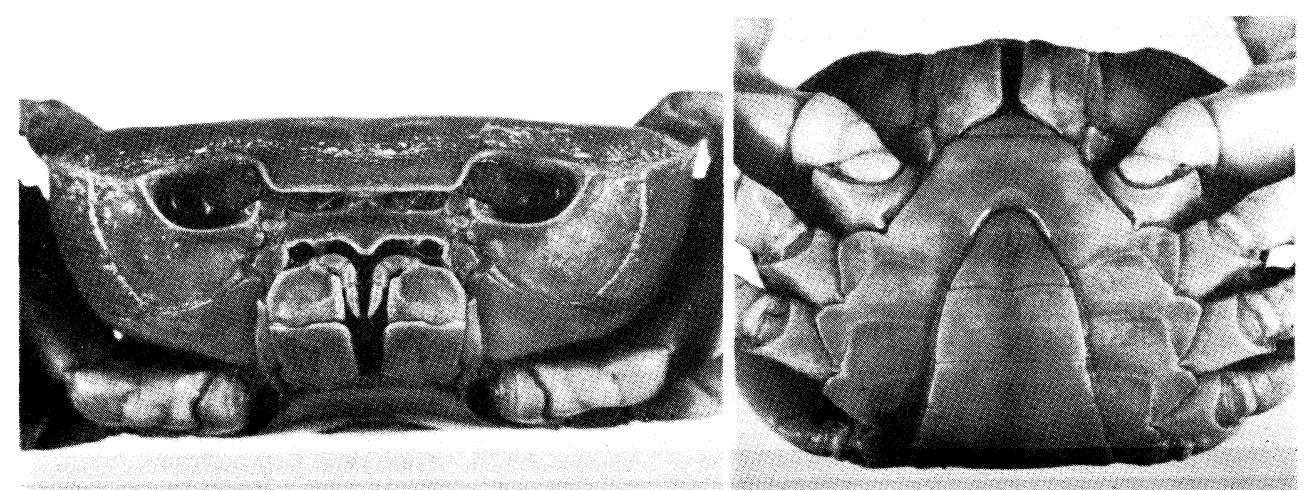

5

6

A new potamonid crab from Formosa 